\title{
Pobieranie próbek gleby w kontekście prowadzenia oceny zanieczyszczenia powierzchni ziemi
}

\begin{abstract}
W artykule omówiono prawodawstwo w zakresie pobierania próbek gleby, obowiązujące podczas prowadzenia oceny zanieczyszczenia powierzchni ziemi. Dokonany przegląd pokazał, że na szczeblu unijnym problem regulacji prawnej związanej z ochroną gleb został dostrzeżony, lecz nadal nie doszło do wprowadzenia jednej dyrektywy poruszającej ten temat. W przypadku regulacji krajowych istnieje rozporządzenie podejmujące zagadnienia związane z pobieraniem próbek gleb w celu dokonania oceny zanieczyszczenia powierzchni ziemi, która powinna być prowadzona na podstawie wiarygodnych wyników wraz z oszacowaną niepewnością, uwzględniającą wszystkie kluczowe składowe. Zaprezentowano wyniki badań otrzymane dla próbek gleby, pobranych zgodnie z omówionymi regulacjami prawnymi. Na podstawie wyników analiz czterech parametrów otrzymanych dla próbek pobranych zgodnie z projektem zrównoważonym (polegającym na wykonaniu dwukrotnych analiz dla dwukrotnie pobranych próbek z ośmiu obiektów), oszacowano niepewność procesu oraz jej składowe (stosując analizę wariancji robust ANOVA). Najbardziej znaczącym udziałem w oszacowanej niepewności procesu $\left(U_{\text {meas }}\right)$ była niepewność pochodząca $\mathrm{z}$ etapu pobierania próbek.
\end{abstract}

Słowa kluczowe: pobieranie próbek, gleba, niepewność.

\section{Soil sampling in the context of land surface pollution assessment}

The article discusses the legislation in the field of soil sampling, which is obligatory during the assessment of soil surface pollution. The review showed that at the EU level, the problem of legal regulation related to soil protection has been noticed, but a single directive dealing with soil protection has not yet been implemented. In the case of national regulations, there is one that deals with issues related to the sampling of soils in order to assess the pollution of the Earth surface. The assessment of ground contamination should be based on reliable results together with estimated uncertainty, which takes into account all key components. The results of the tests obtained for the soil samples that have been collected according to mentioned legal regulations have been presented and discussed. The article shows the results of empirical methodology (robust ANOVA) using data from balanced experimental design, which includes duplicate samples analyzed in duplicate from 8 sampling targets. Robust ANOVA methodology is used for the estimation of the uncertainty arising from the manual sampling of soils and determination of four tested parameters. Based on the results of the study, it was found that the most significant contribution to the estimated uncertainty of the process $\left(U_{\text {meas }}\right)$, was the uncertainty arising from sampling.

Key words: sampling, soil, uncertainty.

\section{Wprowadzenie}

Tematyka gleb jest obecna w prawodawstwie krajowym i europejskim. Zasady ochrony gleb są określone w wielu aktach pośrednich, które dotyczą jednak w głównym stopniu innych komponentów środowiska. Rozproszenie tematu ochrony środowiska glebowego oraz brak skonkretyzowanej wizji działania ma negatywny wpływ na jego ochronę, pozostawiając pole do działania władzom krajowym. Mimo tego, że na szczeblu unijnym problem regulacji prawnej związanej z ochroną gleb został dostrzeżony, nadal nie doszło do wprowadzenia dyrektywy glebowej.

W prawodawstwie polskim ochronę środowiska glebowego reguluje rozporządzenie Ministra Środowiska z dnia 1 września 2016 r. w sprawie sposobu prowadzenia oceny zanieczyszczenia powierzchni ziemi [19], które jest wynikiem prac nad implementacją do prawa polskiego przepisów Dyrektywy IED, tj. Dyrektywy Parlamentu Europejskiego i Rady 2010/75/UE 
z dnia 24 listopada 2010 r. w sprawie emisji przemysłowych (zintegrowane zapobieganie zanieczyszczeniom i ich kontrola) (Dz.U. UE L 334 z 17 grudnia 2010 r., wraz z późn. zm.) [12]. Rozporządzenie to [19] określa, w jaki sposób powinny zostać pobrane, przygotowane oraz zbadane próbki gleby do oceny zanieczyszczenia powierzchni ziemi, podaje również odpowiednie metodyki referencyjne.

Przydatne w określonym celu wyniki badań i pomiarów otrzymywane są jedynie, gdy w sposób właściwy oszacowana jest także ich niepewność. Taka sytuacja ma również miejsce w przypadku przeprowadzania kompleksowej oceny powierzchni ziemi. Dlatego niezwykle istotne jest wykorzystywanie skutecznych procedur szacowania niepewności uwzględ- niających wszystkie etapy procesu pomiarowego/badawczego, w tym także pochodzące $\mathrm{z}$ etapu pobierania reprezentatywnych próbek do badań [4].

$\mathrm{Z}$ uwagi na to, że pobieranie próbek gleby stanowi jeden z kluczowych etapów prowadzenia oceny powierzchni ziemi, próbki gleby pobrane zostały zgodnie z wytycznymi zawartymi w normach [14-18] rekomendowanych przez rozporządzenie [19]. W pobranych próbkach gleby oznaczone zostały cztery parametry ( $\mathrm{pH} \mathrm{w} \mathrm{H}_{2} \mathrm{O}, \mathrm{pH} \mathrm{w} \mathrm{KCl}$, przewodność elektryczna właściwa oraz zawartość wody) i na podstawie otrzymanych wyników badań oszacowano niepewność pochodzącą z etapu pobierania próbek oraz niepewność pomiaru.

\section{Regulacje prawne związane z pobieraniem próbek gleb}

Polityka europejska skupia się na różnych aspektach środowiska. Obejmuje ona między innymi: wodę, atmosferę, odpady, substancje niebezpieczne czy hałas. Brakuje jednak jednoznacznych uregulowań, które dotyczyłyby ściśle środowiska glebowego. Dodatkowo, część z istniejących opracowań współistnieje ze sobą, częściowo powtarzając, a częściowo rozszerzając pojęcia dotyczące degradacji i rekultywacji gleb [7, 9].

Wynikiem prac nad implementacją do prawa polskiego przepisów Dyrektywy IED, tj. Dyrektywy Parlamentu Europejskiego i Rady 2010/75/UE z 24 listopada 2010 r. w sprawie emisji przemysłowych (zintegrowane zapobieganie zanieczyszczeniom i ich kontrola) (Dz.U. UE L 334 z 17 grudnia 2010 r., wraz z późn. zm.) [12] jest rozporządzenie Ministra Środowiska z dnia 1 września 2016 r. w sprawie sposobu prowadzenia oceny zanieczyszczenia powierzchni ziemi [19]. Regulacje związane z ochroną powierzchni ziemi opisane w Dyrektywie IED mają charakter szczątkowy i zostały zawarte w art. 3 pkt 18, 19, 21; art. 12 ust. 1 lit. e); art. 14 ust. 1 lit. e) oraz art. 22 Dyrektywy [12]. Artykuł 22 Dyrektywy [12] stanowi, że w przypadku gdy działalność obejmuje wykorzystywanie, produkcję lub uwalnianie substancji stwarzających zagrożenie oraz mając na uwadze możliwość skażenia gleby i wód podziemnych na terenie instalacji, operator przygotowuje i przedkłada właściwemu organowi sprawozdanie bazowe przed rozpoczęciem eksploatacji instalacji lub przed uaktualnieniem pozwolenia na instalację [12].

Rozporządzenie Ministra Środowiska z dnia 1 września 2016 r. w sprawie sposobu prowadzenia oceny zanieczyszczenia powierzchni ziemi [19] określa, w jaki sposób powinny zostać pobrane, przygotowane oraz zbadane próbki gleby do oceny zanieczyszczenia powierzchni ziemi. W załączniku nr 3 rozporządzenia [19] podano bowiem:
- metodyki referencyjne określania schematu lokalizacji punktów pobierania próbek oraz rodzajów, głębokości i sposobu pobierania próbek do badań, a także ich transportu i przechowywania,

- metodyki referencyjne przygotowania próbek do badań właściwości gleby i ziemi oraz pomiarów zawartości substancji powodujących ryzyko w glebie lub w ziemi,

- metodyki referencyjne badania właściwości gleby lub ziemi oraz

- metodyki referencyjne pomiarów zawartości substancji powodujących ryzyko w glebie lub w ziemi.

Zgodnie z rozporządzeniem [19] pobieranie próbek w terenie, ich utrwalanie, przechowywanie, transport oraz przygotowanie do analizy laboratoryjnej powinno odbywać się na podstawie zasad określonych w następujących normach:

- PN-ISO 10381-1 Jakość gleby - Pobieranie próbekCzęść 1: Zasady opracowywania programów pobierania próbek [14],

- PN-ISO 10381-2 Jakość gleby - Pobieranie próbekCzesść 2: Zasady dotyczace technik pobierania [15],

- PN-ISO 10381-3 Jakość gleby - Pobieranie próbekCzęść 3: Zasady dotyczace bezpieczeństwa [16],

- PN-ISO 10381-4 Jakość gleby - Pobieranie próbekCzesść 4: Zasady dotyczace postępowania podczas badań terenów naturalnych, zbliżonych do naturalnych oraz uprawnych [17],

- PN-ISO 10381-5 Jakość gleby-Pobieranie próbek-Czesść 5: Zasady podczas prowadzenia badań terenów miejskich oraz przemysłowych pod katem zanieczyszczenia gleby [18].

Dodatkowo zgodnie z zapisami rozporządzenia [19] szczegółowe zasady obowiązujące $\mathrm{w}$ trakcie pobierania i przygotowania próbek do badań, określone dla niektórych substancji podanych w rozporządzeniu [19], są opisane w normach dotyczących oznaczania poszczególnych substancji. 


\section{Schemat postępowania i badany obiekt}

Próbki gleby zostały pobrane w dwóch miejscowościach, zlokalizowanych niedaleko Krakowa (miejscowości oznaczono symbolami: B i G). W terenie pobrano próbki pojedyncze w dwóch powtórzeniach, z których po przetransportowaniu do laboratorium zostały przygotowane próbki złożone (zbiorcze). Próbki były pobrane z dwóch głębokości (próbki oznaczone symbolem „, $\mathrm{x}$ ” - od 0 do $0,3 \mathrm{~m}$ ppt, natomiast oznaczone jako ,y”- od 0,3 m do 1,5 m ppt). Po przygotowaniu w laboratorium próbek złożonych oznaczono w nich cztery parametry $\left(\mathrm{pH} w \mathrm{KCl}, \mathrm{pH} w \mathrm{H}_{2} \mathrm{O}\right.$, zawartość wody i przewod- ność elektryczną właściwą), a następnie na podstawie otrzymanych wartości oszacowano niepewność pomiaru i niepewność pobierania próbek.

Schematy pobierania próbek zostały przedstawione na rysunkach 1-4. Symbolami BA, BB, BC, BD zostały opisane obszary, z których pobierano próbki w miejscowości B, natomiast symbolami GA, GB, GC, GD - obszary w miejscowości G. Z każdego obszaru otrzymano po cztery próbki złożone (po dwie z każdej głębokości). Sposób utworzenia próbek został przedstawiony w tablicach $1-4$.
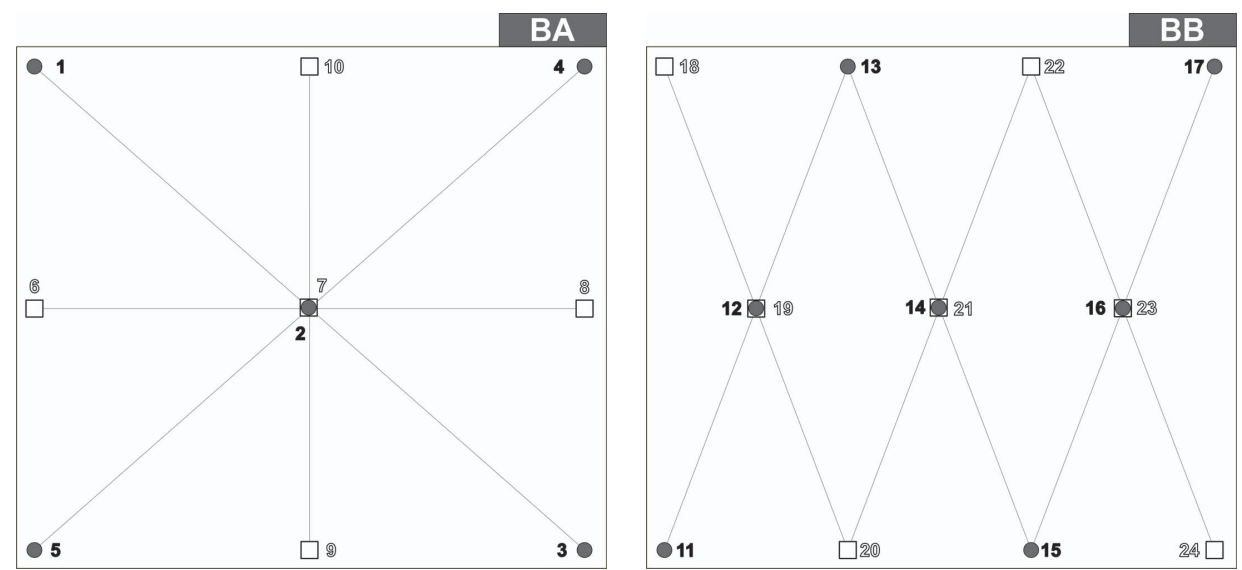

Rys. 1. Schematy pobierania próbek wykorzystywane na obszarach BA oraz BB w miejscowości B

Tablica 1. Informacje dotyczące miejsca pobrania, próbek zbiorczych oraz jednostkowych pobranych na terenie obszarów BA i BB w miejscowości B

\begin{tabular}{|c|c|c|c|c|}
\hline Miejscowość & $\begin{array}{c}\text { Symbol/wielkość } \\
\text { obszaru }\end{array}$ & Próbki jednostkowe & Próbka zbiorcza & $\begin{array}{l}\text { Głębokość pobrania } \\
{[\mathrm{m} \mathrm{ppt}]}\end{array}$ \\
\hline \multirow{8}{*}{$\mathrm{B}$} & \multirow{4}{*}{$\begin{array}{c}\text { BA } \\
(25 \mathrm{~m} \times 20 \mathrm{~m})\end{array}$} & $1 \mathrm{X}, 2 \mathrm{X}, 3 \mathrm{X}, 4 \mathrm{X}, 5 \mathrm{X}$ & $1 \mathrm{x}$ & $0,0 \div 0,3$ \\
\hline & & $1 \mathrm{Y}, 2 \mathrm{Y}, 3 \mathrm{Y}, 4 \mathrm{Y}, 5 \mathrm{Y}$ & $1 \mathrm{y}$ & $0,3 \div 1,5$ \\
\hline & & $6 \mathrm{X}, 7 \mathrm{X}, 8 \mathrm{X}, 9 \mathrm{X}, 10 \mathrm{X}$ & $2 \mathrm{x}$ & $0,0 \div 0,3$ \\
\hline & & $6 \mathrm{Y}, 7 \mathrm{Y}, 8 \mathrm{Y}, 9 \mathrm{Y}, 10 \mathrm{Y}$ & $2 y$ & $0,3 \div 1,5$ \\
\hline & \multirow{4}{*}{$\begin{array}{c}\mathrm{BB} \\
(25 \mathrm{~m} \times 20 \mathrm{~m})\end{array}$} & $11 X, 12 X, 13 X, 14 X, 15 X, 16 X, 17 X$ & $3 x$ & $0,0 \div 0,3$ \\
\hline & & $11 \mathrm{Y}, 12 \mathrm{Y}, 13 \mathrm{Y}, 14 \mathrm{Y}, 15 \mathrm{Y}, 16 \mathrm{Y}, 17 \mathrm{Y}$ & $4 y$ & $0,3 \div 1,5$ \\
\hline & & $18 \mathrm{X}, 19 \mathrm{X}, 20 \mathrm{X}, 21 \mathrm{X}, 22 \mathrm{X}, 23 \mathrm{X}, 24 \mathrm{X}$ & $3 \mathrm{x}$ & $0,0 \div 0,3$ \\
\hline & & 18Y, 19Y, 20Y, 21Y, 22Y, 23Y, 24Y & $4 y$ & $0,3 \div 1,5$ \\
\hline
\end{tabular}

BC

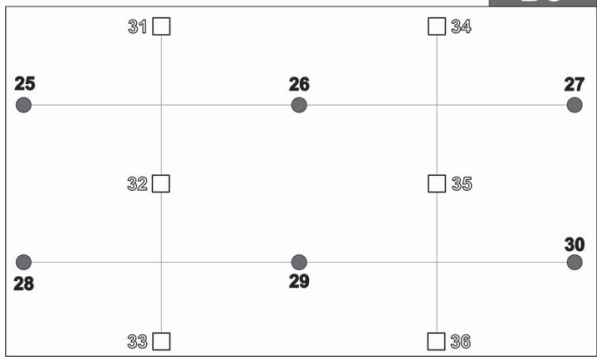

BD

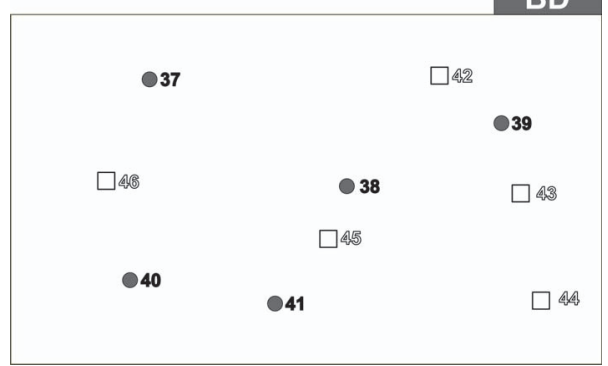

Rys. 2. Schematy pobierania próbek wykorzystywane na obszarach BC oraz BD w miejscowości B 


\section{NAFTA-GAZ}

Tablica 2. Informacje dotyczące próbek zbiorczych oraz jednostkowych pobranych na terenie obszarów BA i BB

\begin{tabular}{|c|c|c|c|c|}
\hline Miejscowość & $\begin{array}{c}\text { Symbol/wielkość } \\
\text { obszaru }\end{array}$ & Próbki jednostkowe & Próbka zbiorcza & $\begin{array}{l}\text { Głębokość pobrania } \\
\text { [m ppt] }\end{array}$ \\
\hline \multirow{8}{*}{$\mathrm{B}$} & \multirow{4}{*}{$\mathrm{BC}(14 \mathrm{~m} \times 10 \mathrm{~m})$} & $25 X, 26 X, 27 X, 28 X, 29 X, 30 X$ & $5 x$ & $0,0 \div 0,3$ \\
\hline & & 25Y, 26Y, 27Y, 28Y, 29Y, 30Y & $6 y$ & $0,3 \div 1,5$ \\
\hline & & $31 X, 32 X, 33 X, 34 X, 35 X, 36 X$ & $5 \mathrm{x}$ & $0,0 \div 0,3$ \\
\hline & & $31 \mathrm{Y}, 32 \mathrm{Y}, 33 \mathrm{Y}, 34 \mathrm{Y}, 35 \mathrm{Y}, 36 \mathrm{Y}$ & $6 y$ & $0,3 \div 1,5$ \\
\hline & \multirow{4}{*}{$\mathrm{BD}(14 \mathrm{~m} \times 10 \mathrm{~m})$} & $37 X, 38 X, 39 X, 40 X, 41 X$ & $7 \mathrm{x}$ & $0,0 \div 0,3$ \\
\hline & & 37Y, 38Y, 39Y, 40Y, 41Y & $8 y$ & $0,3 \div 1,5$ \\
\hline & & $42 X, 43 X, 44 X, 45 X, 46 X$ & $7 \mathrm{x}$ & $0,0 \div 0,3$ \\
\hline & & $42 \mathrm{Y}, 43 \mathrm{Y}, 44 \mathrm{Y}, 45 \mathrm{Y}, 46 \mathrm{Y}$ & $8 y$ & $0,3 \div 1,5$ \\
\hline
\end{tabular}

\section{GA}

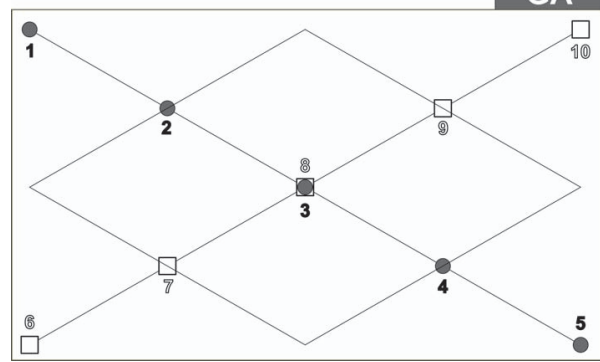

GB

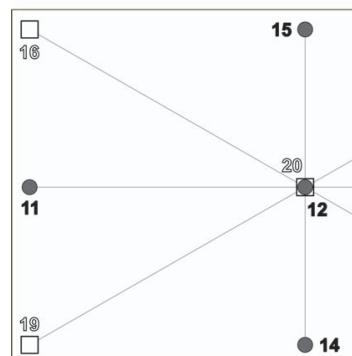

$?_{98}$

$\stackrel{13}{2}$

$\stackrel{18}{\square}$

Rys. 3. Schematy pobierania próbek wykorzystywane na obszarach GA oraz GB w miejscowości G

Tablica 3. Dane dotyczące miejsca pobrania, próbek zbiorczych oraz jednostkowych pobranych na terenie obszarów GA i GB w miejscowości G

\begin{tabular}{|c|c|c|c|c|}
\hline Miejscowość & $\begin{array}{c}\text { Symbol/wielkość } \\
\text { obszaru }\end{array}$ & Próbki jednostkowe & Próbka zbiorcza & $\begin{array}{l}\text { Głębokość pobrania } \\
{[\mathrm{m} \mathrm{ppt}]}\end{array}$ \\
\hline \multirow{8}{*}{ G } & \multirow{4}{*}{$\mathrm{GA}(24 \mathrm{~m} \times 12 \mathrm{~m})$} & $1 X, 2 X, 3 X, 4 X, 5 X$ & $9 x$ & $0,0 \div 0,3$ \\
\hline & & $1 \mathrm{Y}, 2 \mathrm{Y}, 3 \mathrm{Y}, 4 \mathrm{Y}, 5 \mathrm{Y}$ & $10 \mathrm{y}$ & $0,3 \div 1,5$ \\
\hline & & $6 X, 7 X, 8 X, 9 X, 10 X$ & $9 x$ & $0,0 \div 0,3$ \\
\hline & & $6 \mathrm{Y}, 7 \mathrm{Y}, 8 \mathrm{Y}, 9 \mathrm{Y}, 10 \mathrm{Y}$ & $10 \mathrm{y}$ & $0,3 \div 1,5$ \\
\hline & \multirow{4}{*}{$\mathrm{GB}(24 \mathrm{~m} \times 12 \mathrm{~m})$} & $11 X, 12 X, 13 X, 14 X, 15 X$ & $11 x$ & $0,0 \div 0,3$ \\
\hline & & $11 \mathrm{Y}, 12 \mathrm{Y}, 13 \mathrm{Y}, 14 \mathrm{Y}, 15 \mathrm{Y}$ & $12 \mathrm{y}$ & $0,3 \div 1,5$ \\
\hline & & $16 X, 17 X, 18 X, 19 X, 20 X$ & $11 x$ & $0,0 \div 0,3$ \\
\hline & & 16Y, 17Y, 18Y, 19Y, 20Y & $12 y$ & $0,3 \div 1,5$ \\
\hline
\end{tabular}

GC

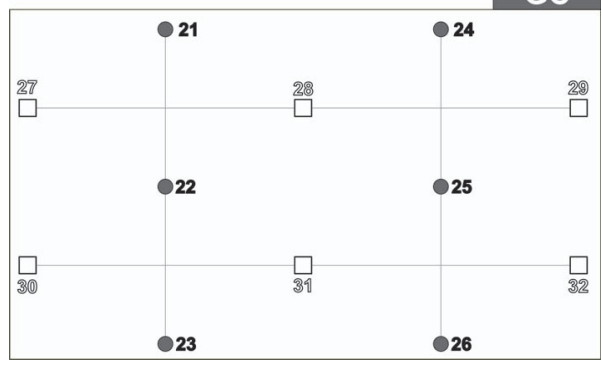

\section{GD}

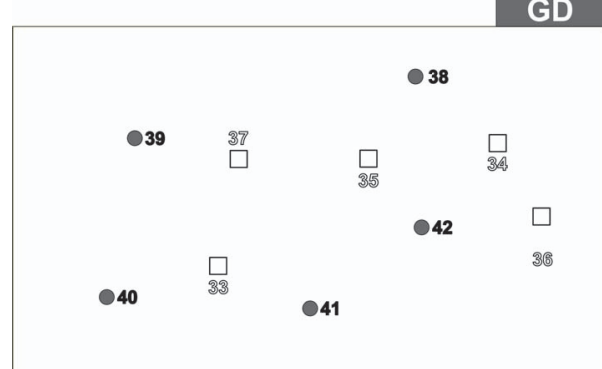

Rys. 4. Schematy pobierania próbek wykorzystywane na obszarach GC oraz GD w miejscowości G 
Tablica 4. Informacje dotyczące próbek zbiorczych oraz jednostkowych pobranych na terenie obszarów GC i GD w miejscowości G

\begin{tabular}{|c|c|c|c|c|}
\hline Miejscowość & $\begin{array}{c}\text { Symbol/ wielkość } \\
\text { obszaru }\end{array}$ & Próbki jednostkowe & Próbka zbiorcza & $\begin{array}{l}\text { Głębokość pobrania } \\
\text { [m ppt] }\end{array}$ \\
\hline \multirow{8}{*}{ G } & \multirow{4}{*}{$\mathrm{GC}(10 \mathrm{~m} \times 5 \mathrm{~m})$} & $21 X, 22 X, 23 X, 24 X, 25 X, 26 X$ & $13 x$ & $0,0 \div 0,3$ \\
\hline & & 21Y, 22Y, 23Y, 24Y, 25Y, 26Y & $14 y$ & $0,3 \div 1,5$ \\
\hline & & 27X, 28X, 29X, 30X 31X, 32X & $13 x$ & $0,0 \div 0,3$ \\
\hline & & $27 \mathrm{Y}, 28 \mathrm{Y}, 29 \mathrm{Y}, 30 \mathrm{Y} 31 \mathrm{Y}, 32 \mathrm{Y}$ & $14 y$ & $0,3 \div 1,5$ \\
\hline & \multirow{4}{*}{$\operatorname{GD}(15 \mathrm{~m} \times 13 \mathrm{~m})$} & $33 X, 34 X, 35 X, 36 X, 37 X$ & $15 \mathrm{x}$ & $0,0 \div 0,3$ \\
\hline & & $33 \mathrm{Y}, 34 \mathrm{Y}, 35 \mathrm{Y}, 36 \mathrm{Y}, 37 \mathrm{Y}$ & $16 y$ & $0,3 \div 1,5$ \\
\hline & & $38 X, 39 X, 40 X, 41 X, 42 X$ & $15 \mathrm{x}$ & $0,0 \div 0,3$ \\
\hline & & 38Y, 39Y, 40Y, 41Y, 42Y & $16 y$ & $0,3 \div 1,5$ \\
\hline
\end{tabular}

\section{Sposób pobrania i przygotowania próbek do badań}

Próbki jednostkowe gleby zostały pobrane za pomocą świdra ręcznego (średnica $25 \mathrm{~cm}$ ) i przechowywane w zamkniętych wiaderkach z tworzywa sztucznego. Natychmiast po pobraniu zostały przetransportowane do laboratorium. Oględzin terenu dokonano $\mathrm{z}$ wykorzystaniem taśmy mierniczej oraz kompasu. Po przewiezieniu do laboratorium próbki pojedyncze zostały rozdrobnione i wymieszane w celu utwo- rzenia próbek zbiorczych. Do utworzenia próbek złożonych zważono po $100 \mathrm{~g}$ do $120 \mathrm{~g}$ próbek jednostkowych (w zależności od liczby próbek jednostkowych tworzących próbkę zbiorczą). Próbki zostały przesiane w celu usunięcia cząstek o wielkości ziaren powyżej $2 \mathrm{~mm}$. Do wykonania pomiarów i oznaczeń użyto rozdrobnionych powietrznie suchych próbek złożonych.

\section{Wyniki badań}

Badania laboratoryjne wykonano w Laboratorium Analityki i Fizykochemii Wód, Ścieków i Odpadów z zachowaniem wymagań normy PN-EN ISO 17025:2005, w zakresie akredytacji $\mathrm{AB}$ 041. W próbkach gleb oznaczono parametry, takie jak:

- zawartość wody (metodą wagową, na podstawie PN-ISO 11465:1999),
- $\mathrm{pH}_{\mathrm{H} 2 \mathrm{O}} \mathrm{i} \mathrm{pH}_{\mathrm{KCl}}$ (metodą elektrochemiczną, zgodnie z PN-ISO 10390:1997),

- przewodność elektryczną właściwą (metodą konduktometryczną, według PN-ISO 11265:1997).

Wyniki otrzymane dla analizowanych próbek gleby zestawiono w tablicach 5-12.

\section{Szacowanie niepewności i analiza danych}

Do oszacowania wartości niepewności całkowitej wykorzystano program ROBAN wersja 1.0.1, który jest dostępny na stronie internetowej Royal Society of Chemistry [10]. Program ten ma zaimplementowane dwa algorytmy analizy wariancji ANOVA - klasycznej analizy wariancji oraz metodę statystyk robust ANOVA (RANOVA), która dopuszcza 10\% wyników odstających. Obydwie metody bazują na wartości średniej arytmetycznej z otrzymanych wyników, która bardzo mocno zależy od obecności wartości odstających w zbiorze wyników. Aby wyeliminować tę zależność, w literaturze spotyka się również zmodyfikowaną metodę RANOVA, w której zamiast średniej arytmetycznej wykorzystywana jest mediana [3, 4]. Z uwagi na to, że w analizowanych w ramach niniejszej pracy zbiorach wyników nie zaobserwowano wartości odbiegających (stosując test statystyczny
Q-Dixona) do szacowania niepewności użyto metod ANOVA oraz RANOVA bazujących na średniej arytmetycznej, natomiast z uwagi na to, że wartości odbiegające w zbiorach mogą się pojawiać (jednak nie spodziewa się przekroczenia 10\%) do interpretacji wyników analiz stosuje się niepewność wyznaczoną za pomocą odpornościowej analizy wariancji RANOVA.

Wykorzystując wyniki analizy wariancji, można obliczyć wartości następujących parametrów:

- wariancję całkowitą $s_{\text {total }}^{2}$ i jej komponenty: wariancję geochemiczną $s_{\text {geoch }}^{2}$, wariancję pobierania $s_{\text {sampl }}^{2}$ oraz wariancję analityczną $s_{\text {anal }}^{2}$,

- niepewność standardową $u_{t o t}=s_{t o t}$ i jej składowe,

- niepewność rozszerzoną $U_{t o t}=2 \cdot u_{t o t}$ dla przedziału ufności 95\% i jej komponenty, 


\section{NAFTA-GAZ}

Tablica 5. Wyniki pomiarów zawartości wody dla próbek pobranych z głębokości $0 \div 0,3 \mathrm{~m} \mathrm{ppt}$

\begin{tabular}{|c|c|c|}
\hline Numer próbki & $\begin{array}{c}\text { Badany obszar } \\
\text { w miejscowości B }\end{array}$ & $\begin{array}{c}\text { Zawartość wody } \\
{[\%]}\end{array}$ \\
\hline \multirow{2}{*}{$1 \mathrm{x}$} & \multirow{4}{*}{ BA } & 11,4 \\
\hline & & 11,5 \\
\hline \multirow{2}{*}{$2 \mathrm{x}$} & & 11,7 \\
\hline & & 12,0 \\
\hline \multirow{2}{*}{$3 x$} & \multirow{4}{*}{$\mathrm{BB}$} & 12,8 \\
\hline & & 12,8 \\
\hline \multirow{2}{*}{$4 \mathrm{x}$} & & 11,4 \\
\hline & & 11,9 \\
\hline \multirow{2}{*}{$5 x$} & \multirow{4}{*}{$\mathrm{BC}$} & 10,1 \\
\hline & & 9,98 \\
\hline \multirow{2}{*}{$6 x$} & & 12,5 \\
\hline & & 12,7 \\
\hline \multirow{2}{*}{$7 \mathrm{x}$} & \multirow{4}{*}{$\mathrm{BD}$} & 9,97 \\
\hline & & 9,90 \\
\hline \multirow{2}{*}{$8 \mathrm{x}$} & & 8,69 \\
\hline & & 9,11 \\
\hline
\end{tabular}

\begin{tabular}{|c|c|c|}
\hline Numer próbki & $\begin{array}{c}\text { Badany obszar } \\
\text { w miejscowości G }\end{array}$ & $\begin{array}{c}\text { Zawartość wody } \\
{[\%]}\end{array}$ \\
\hline \multirow{2}{*}{$9 x$} & \multirow{4}{*}{ GA } & 14,0 \\
\hline & & 14,1 \\
\hline \multirow{2}{*}{$10 \mathrm{x}$} & & 12,0 \\
\hline & & 12,3 \\
\hline \multirow{2}{*}{$11 x$} & \multirow{4}{*}{ GB } & 13,4 \\
\hline & & 13,3 \\
\hline \multirow{2}{*}{$12 x$} & & 13,1 \\
\hline & & 13,1 \\
\hline \multirow{2}{*}{$13 x$} & \multirow{4}{*}{$\mathrm{GC}$} & 14,0 \\
\hline & & 13,9 \\
\hline \multirow{2}{*}{$14 x$} & & 14,3 \\
\hline & & 14,1 \\
\hline \multirow{2}{*}{$15 x$} & \multirow{4}{*}{ GD } & 20,9 \\
\hline & & 20,2 \\
\hline \multirow{2}{*}{$16 x$} & & 19,1 \\
\hline & & 18,8 \\
\hline
\end{tabular}

Tablica 6. Wyniki pomiarów zawartości wody dla próbek pobranych z głębokości $0,3 \div 1,5 \mathrm{~m} \mathrm{ppt}$

\begin{tabular}{|c|c|c|}
\hline Numer próbki & $\begin{array}{c}\text { Badany obszar } \\
\text { w miejscowości B }\end{array}$ & $\begin{array}{c}\text { Zawartość wody } \\
{[\%]}\end{array}$ \\
\hline \multirow{2}{*}{$1 y$} & \multirow{4}{*}{ BA } & 14,4 \\
\hline & & 14,3 \\
\hline \multirow{2}{*}{$2 y$} & & 14,0 \\
\hline & & 14,1 \\
\hline \multirow{2}{*}{$3 y$} & \multirow{4}{*}{$\mathrm{BB}$} & 12,3 \\
\hline & & 12,4 \\
\hline \multirow{2}{*}{$4 y$} & & 12,9 \\
\hline & & 12,4 \\
\hline \multirow{2}{*}{$5 y$} & \multirow{4}{*}{$\mathrm{BC}$} & 10,3 \\
\hline & & 10,3 \\
\hline \multirow{2}{*}{$6 y$} & & 11,4 \\
\hline & & 11,3 \\
\hline \multirow{2}{*}{$7 y$} & \multirow{4}{*}{$\mathrm{BD}$} & 12,0 \\
\hline & & 11,8 \\
\hline \multirow{2}{*}{$8 y$} & & 10,7 \\
\hline & & 10,7 \\
\hline
\end{tabular}

\begin{tabular}{|c|c|c|}
\hline Numer próbki & $\begin{array}{c}\text { Badany obszar } \\
\text { w miejscowości G }\end{array}$ & $\begin{array}{c}\text { Zawartość wody } \\
{[\%]}\end{array}$ \\
\hline \multirow{2}{*}{$9 y$} & \multirow{4}{*}{ GA } & 14,6 \\
\hline & & 14,7 \\
\hline \multirow{2}{*}{$10 y$} & & 13,8 \\
\hline & & 13,7 \\
\hline \multirow{2}{*}{$11 y$} & \multirow{4}{*}{ GB } & 14,2 \\
\hline & & 13,9 \\
\hline \multirow{2}{*}{$12 \mathrm{y}$} & & 14,3 \\
\hline & & 14,2 \\
\hline \multirow{2}{*}{$13 y$} & \multirow{4}{*}{ GC } & 14,1 \\
\hline & & 14,1 \\
\hline \multirow{2}{*}{$14 y$} & & 13,8 \\
\hline & & 14,2 \\
\hline \multirow{2}{*}{$15 y$} & \multirow{4}{*}{ GD } & 13,6 \\
\hline & & 13,5 \\
\hline \multirow{2}{*}{$16 y$} & & 15,2 \\
\hline & & 15,1 \\
\hline
\end{tabular}

- niepewność względną wyniku pomiaru $U_{\text {total }}^{\prime}$ i jej składowe $[1,2,4,10]$.

W praktyce zmienności populacji zastępuje się oszacowaniami, co daje:

$$
s_{\text {total }}^{2}=s_{\text {geoch }}^{2}+s_{\text {sampl }}^{2}+s_{\text {anal }}^{2}
$$

Niepewność pomiaru wynosi zatem:

$$
u_{\text {meas }}=s_{\text {meas }}=\sqrt{s_{\text {sampl }}^{2}+s_{\text {anal }}^{2}}
$$

Wartości $s_{\text {sampl }}$ oraz $s_{\text {anal }}$ są odpowiednio oszacowaniami precyzji procesu pobierania próbki i precyzji procesu analitycznego. Losowy składnik niepewności pomiaru oblicza się, łącząc te dwa oszacowania. 
Tablica 7. Wyniki pomiarów $\mathrm{pH}_{\mathrm{H} 2 \mathrm{O}}$ dla próbek pobranych z głębokości $0 \div 0,3 \mathrm{~m} \mathrm{ppt}$

\begin{tabular}{|c|c|c|}
\hline Numer próbki & $\begin{array}{c}\text { Badany obszar } \\
\text { w miejscowości B }\end{array}$ & Wynik pH ${ }_{\mathrm{H} 2 \mathrm{O}}$ \\
\hline \multirow{2}{*}{$1 x$} & \multirow{4}{*}{ BA } & 6,68 \\
\hline & & 6,64 \\
\hline \multirow{2}{*}{$2 \mathrm{x}$} & & 6,54 \\
\hline & & 6,55 \\
\hline \multirow{2}{*}{$3 x$} & \multirow{4}{*}{ BB } & 6,42 \\
\hline & & 6,44 \\
\hline \multirow{2}{*}{$4 \mathrm{x}$} & & 6,34 \\
\hline & & 6,38 \\
\hline \multirow{2}{*}{$5 x$} & \multirow{4}{*}{$\mathrm{BC}$} & 6,37 \\
\hline & & 6,37 \\
\hline \multirow{2}{*}{$6 x$} & & 6,52 \\
\hline & & 6,52 \\
\hline \multirow{2}{*}{$7 \mathrm{x}$} & \multirow{4}{*}{$\mathrm{BD}$} & 6,61 \\
\hline & & 6,61 \\
\hline \multirow{2}{*}{$8 \mathrm{x}$} & & 6,71 \\
\hline & & 6,70 \\
\hline
\end{tabular}

\begin{tabular}{|c|c|c|}
\hline Numer próbki & $\begin{array}{c}\text { Badany obszar } \\
\text { w miejscowości G }\end{array}$ & Wynik $\mathrm{pH}_{\mathrm{H} 2 \mathrm{O}}$ \\
\hline \multirow{2}{*}{$9 x$} & \multirow{4}{*}{ GA } & 6,07 \\
\hline & & 6,12 \\
\hline \multirow{2}{*}{$10 \mathrm{x}$} & & 5,81 \\
\hline & & 5,84 \\
\hline \multirow{2}{*}{$11 x$} & \multirow{4}{*}{ GB } & 5,40 \\
\hline & & 5,50 \\
\hline \multirow{2}{*}{$12 \mathrm{x}$} & & 5,50 \\
\hline & & 5,56 \\
\hline \multirow{2}{*}{$13 x$} & \multirow{4}{*}{$\mathrm{GC}$} & 5,44 \\
\hline & & 5,45 \\
\hline \multirow{2}{*}{$14 x$} & & 5,49 \\
\hline & & 5,48 \\
\hline \multirow{2}{*}{$15 \mathrm{x}$} & \multirow{4}{*}{ GD } & 4,28 \\
\hline & & 4,24 \\
\hline \multirow{2}{*}{$16 x$} & & 4,43 \\
\hline & & 4,39 \\
\hline
\end{tabular}

Tablica 8. Wyniki pomiarów $\mathrm{pH}_{\mathrm{H} 2 \mathrm{O}}$ dla próbek pobranych z głębokości $0,3 \div 1,5 \mathrm{~m} \mathrm{ppt}$

\begin{tabular}{|c|c|c|}
\hline Numer próbki & $\begin{array}{c}\text { Badany obszar } \\
\text { w miejscowości B }\end{array}$ & Wynik $\mathrm{pH}_{\mathrm{H} 2 \mathrm{O}}$ \\
\hline \multirow{2}{*}{$1 y$} & \multirow{4}{*}{$\mathrm{BA}$} & 6,96 \\
\hline & & 6,91 \\
\hline \multirow{2}{*}{$2 y$} & & 6,87 \\
\hline & & 6,84 \\
\hline \multirow{2}{*}{$3 y$} & \multirow{4}{*}{$\mathrm{BB}$} & 6,43 \\
\hline & & 6,46 \\
\hline \multirow{2}{*}{$4 y$} & & 6,40 \\
\hline & & 6,41 \\
\hline \multirow{2}{*}{$5 y$} & \multirow{4}{*}{$\mathrm{BC}$} & 6,64 \\
\hline & & 6,63 \\
\hline \multirow{2}{*}{$6 y$} & & 6,85 \\
\hline & & 6,84 \\
\hline \multirow{2}{*}{$7 y$} & \multirow{4}{*}{$\mathrm{BD}$} & 6,96 \\
\hline & & 6,97 \\
\hline \multirow{2}{*}{$8 y$} & & 7,00 \\
\hline & & 6,97 \\
\hline
\end{tabular}

\begin{tabular}{|c|c|c|}
\hline Numer próbki & $\begin{array}{c}\text { Badany obszar } \\
\text { w miejscowości G }\end{array}$ & Wynik $\mathrm{pH}_{\text {н2О }}$ \\
\hline \multirow{2}{*}{$9 y$} & \multirow{4}{*}{ GA } & 5,45 \\
\hline & & 5,44 \\
\hline \multirow{2}{*}{$10 y$} & & 5,44 \\
\hline & & 5,43 \\
\hline \multirow{2}{*}{$11 y$} & \multirow{4}{*}{ GB } & 5,49 \\
\hline & & 5,52 \\
\hline \multirow{2}{*}{$12 y$} & & 5,58 \\
\hline & & 5,55 \\
\hline \multirow{2}{*}{$13 y$} & \multirow{4}{*}{$\mathrm{GC}$} & 5,64 \\
\hline & & 5,68 \\
\hline \multirow{2}{*}{$14 y$} & & 5,59 \\
\hline & & 5,63 \\
\hline \multirow{2}{*}{$15 y$} & \multirow{4}{*}{ GD } & 4,37 \\
\hline & & 4,31 \\
\hline \multirow{2}{*}{$16 y$} & & 4,59 \\
\hline & & 4,59 \\
\hline
\end{tabular}

Niepewność rozszerzoną (dla przedziału ufności 95\%) otrzymujemy przez pomnożenie otrzymanej wartości przez współczynnik rozszerzenia 2:

$$
U_{\text {meas }}=2 s_{\text {meas }}
$$

Niepewność rozszerzoną $U$ można także wyrazić w odniesieniu do podawanej wartości wyniku pomiaru $x$, jako względną niepewność rozszerzoną $U_{\text {meas }}^{\prime}$, wyrażoną w procentach:

$$
U_{\text {meas }}^{\prime}=\frac{2 s_{\text {meas }}}{x} \cdot 100[\%]
$$

Względne niepewności samego pobierania próbki $U_{\text {sampl }}^{\prime}$ lub pomiaru $U_{\text {anal }}^{\prime}$ są natomiast opisane zależnościami $[4,8,10]$ : 
Tablica 9. Wyniki pomiarów $\mathrm{pH}_{\mathrm{KCl}}$ dla próbek pobranych z głębokości $0 \div 0,3 \mathrm{~m} \mathrm{ppt}$

\begin{tabular}{|c|c|c|}
\hline Numer próbki & $\begin{array}{c}\text { Badany obszar } \\
\text { w miejscowości B }\end{array}$ & Wynik $\mathrm{pH}_{\mathrm{KCl}}$ \\
\hline $1 \mathrm{y}$ & \multirow{4}{*}{ BA } & 5,93 \\
\hline $11 \mathrm{x}$ & & 5,91 \\
\hline \multirow{2}{*}{$2 \mathrm{x}$} & & 5,84 \\
\hline & & 5,81 \\
\hline \multirow{2}{*}{$3 x$} & \multirow{4}{*}{$\mathrm{BB}$} & 5,80 \\
\hline & & 5,82 \\
\hline \multirow{2}{*}{$4 \mathrm{x}$} & & 5,76 \\
\hline & & 5,73 \\
\hline \multirow{2}{*}{$5 \mathrm{x}$} & \multirow{4}{*}{$\mathrm{BC}$} & 5,71 \\
\hline & & 5,70 \\
\hline \multirow{2}{*}{$6 x$} & & 5,81 \\
\hline & & 5,82 \\
\hline \multirow{2}{*}{$7 \mathrm{x}$} & \multirow{4}{*}{$\mathrm{BD}$} & 6,09 \\
\hline & & 6,07 \\
\hline \multirow{2}{*}{$8 \mathrm{x}$} & & 6,11 \\
\hline & & 6,15 \\
\hline
\end{tabular}

\begin{tabular}{|c|c|c|}
\hline Numer próbki & $\begin{array}{c}\text { Badany obszar } \\
\text { w miejscowości G }\end{array}$ & Wynik $\mathrm{pH}_{\mathrm{KCl}}$ \\
\hline \multirow{2}{*}{$9 x$} & \multirow{4}{*}{ GA } & 4,71 \\
\hline & & 4,69 \\
\hline \multirow{2}{*}{$10 \mathrm{x}$} & & 4,51 \\
\hline & & 4,49 \\
\hline \multirow{2}{*}{$11 x$} & \multirow{4}{*}{ GB } & 4,28 \\
\hline & & 4,28 \\
\hline \multirow{2}{*}{$12 x$} & & 4,22 \\
\hline & & 4,22 \\
\hline \multirow{2}{*}{$13 x$} & \multirow{4}{*}{$\mathrm{GC}$} & 4,09 \\
\hline & & 4,09 \\
\hline \multirow{2}{*}{$14 \mathrm{x}$} & & 4,06 \\
\hline & & 4,07 \\
\hline \multirow{2}{*}{$15 x$} & \multirow{4}{*}{ GD } & 3,39 \\
\hline & & 3,36 \\
\hline \multirow{2}{*}{$16 \mathrm{x}$} & & 3,58 \\
\hline & & 3,57 \\
\hline
\end{tabular}

Tablica 10. Wyniki pomiarów $\mathrm{pH}_{\mathrm{KCl}}$ dla próbek pobranych z głębokości $0,3 \div 1,5 \mathrm{~m} \mathrm{ppt}$

\begin{tabular}{|c|c|c|}
\hline Numer próbki & $\begin{array}{c}\text { Badany obszar } \\
\text { w miejscowości B }\end{array}$ & Wynik $\mathrm{pH}_{\mathrm{KCl}}$ \\
\hline \multirow{2}{*}{$1 y$} & \multirow{4}{*}{ BA } & 6,04 \\
\hline & & 6,07 \\
\hline \multirow{2}{*}{$2 y$} & & 5,91 \\
\hline & & 5,89 \\
\hline \multirow{2}{*}{$3 y$} & \multirow{4}{*}{$\mathrm{BB}$} & 5,00 \\
\hline & & 4,96 \\
\hline \multirow{2}{*}{$4 y$} & & 4,78 \\
\hline & & 4,79 \\
\hline \multirow{2}{*}{$5 y$} & \multirow{4}{*}{$\mathrm{BC}$} & 5,67 \\
\hline & & 5,68 \\
\hline \multirow{2}{*}{$6 y$} & & 5,79 \\
\hline & & 5,81 \\
\hline \multirow{2}{*}{$7 y$} & \multirow{4}{*}{$\mathrm{BD}$} & 6,02 \\
\hline & & 5,99 \\
\hline \multirow{2}{*}{$8 y$} & & 6,05 \\
\hline & & 6,06 \\
\hline
\end{tabular}

\begin{tabular}{|c|c|c|}
\hline Numer próbki & $\begin{array}{c}\text { Badany obszar } \\
\text { w miejscowości G }\end{array}$ & Wynik $\mathrm{pH}_{\mathrm{KCl}}$ \\
\hline \multirow{2}{*}{$9 y$} & \multirow{4}{*}{ GA } & 3,97 \\
\hline & & 3,95 \\
\hline \multirow{2}{*}{$10 y$} & & 3,89 \\
\hline & & 3,91 \\
\hline \multirow{2}{*}{$11 y$} & \multirow{4}{*}{ GB } & 4,07 \\
\hline & & 4,10 \\
\hline \multirow{2}{*}{$12 y$} & & 4,02 \\
\hline & & 4,07 \\
\hline \multirow{2}{*}{$13 y$} & \multirow{4}{*}{$\mathrm{GC}$} & 4,00 \\
\hline & & 3,98 \\
\hline \multirow{2}{*}{$14 y$} & & 3,97 \\
\hline & & 3,98 \\
\hline \multirow{2}{*}{$15 y$} & \multirow{4}{*}{ GD } & 3,62 \\
\hline & & 3,65 \\
\hline \multirow{2}{*}{$16 y$} & & 3,61 \\
\hline & & 3,60 \\
\hline
\end{tabular}

$$
\begin{aligned}
U_{\text {sampl }}^{\prime} & =\frac{2 s_{\text {sampl }}}{x} \cdot 100 \\
U_{\text {anal }}^{\prime} & =\frac{2 s_{\text {anal }}}{x} \cdot 100
\end{aligned}
$$

Wyniki przeprowadzonych obliczeń zostały zebrane w tablicy 13 .

Zgodnie z wytycznymi zawartymi w literaturze $[2,8]$ udział wariancji pomiaru $s_{\text {meas }}^{2}\left(s_{\text {meas }}^{2}=s_{\text {sampl }}^{2}+s_{\text {anal }}^{2}\right) \mathrm{w}$ wariancji całkowitej $s_{\text {total }}^{2}$ nie powinien przekroczyć $20 \% s_{\text {total }}^{2}$, natomiast $s_{\text {anal }}^{2}$ nie powinna przekraczać $4 \% s_{\text {total }}^{2}$, ponieważ wówczas wariancja $s_{\text {meas }}^{2}$ byłaby uwarunkowana niepewnością analityczną. Powyższe warunki są spełnione dla wszystkich analizowanych zbiorów wyników pomiarów i badań. 
Tablica 11. Wyniki pomiarów przewodności elektrycznej właściwej dla próbek pobranych z głębokości 0 $\div 0,3 \mathrm{~m} \mathrm{ppt}$

\begin{tabular}{|c|c|c|}
\hline Numer próbki & $\begin{array}{c}\text { Badany obszar } \\
\text { w miejscowości B }\end{array}$ & $\begin{array}{c}\text { Przewodność } \\
{[\mu \mathrm{S} / \mathrm{cm}]}\end{array}$ \\
\hline \multirow{2}{*}{$1 \mathrm{x}$} & \multirow{4}{*}{$\mathrm{BA}$} & 111,0 \\
\hline & & 116,9 \\
\hline \multirow{2}{*}{$2 \mathrm{x}$} & & 116,3 \\
\hline & & 121,8 \\
\hline \multirow{2}{*}{$3 x$} & \multirow{4}{*}{$\mathrm{BB}$} & 136,6 \\
\hline & & 131,6 \\
\hline \multirow{2}{*}{$4 \mathrm{x}$} & & 141,3 \\
\hline & & 129,1 \\
\hline \multirow{2}{*}{$5 \mathrm{x}$} & \multirow{4}{*}{$\mathrm{BC}$} & 115,9 \\
\hline & & 108,9 \\
\hline \multirow{2}{*}{$6 x$} & & 112,3 \\
\hline & & 111,3 \\
\hline \multirow{2}{*}{$7 \mathrm{x}$} & \multirow{4}{*}{$\mathrm{BD}$} & 98,2 \\
\hline & & 91,4 \\
\hline \multirow{2}{*}{$8 \mathrm{x}$} & & 107,1 \\
\hline & & 104,0 \\
\hline
\end{tabular}

\begin{tabular}{|c|c|c|}
\hline Numer próbki & $\begin{array}{c}\text { Badany obszar w } \\
\text { miejscowości G }\end{array}$ & $\begin{array}{c}\text { Przewodność } \\
{[\mu \mathrm{S} / \mathrm{cm}]}\end{array}$ \\
\hline \multirow{2}{*}{$9 \mathrm{x}$} & \multirow{4}{*}{ GA } & 38,7 \\
\hline & & 26,2 \\
\hline \multirow{2}{*}{$10 \mathrm{x}$} & & 39,9 \\
\hline & & 44,8 \\
\hline \multirow{2}{*}{$11 x$} & \multirow{4}{*}{ GB } & 31,3 \\
\hline & & 33,8 \\
\hline \multirow{2}{*}{$12 x$} & & 34,2 \\
\hline & & 35,2 \\
\hline \multirow{2}{*}{$13 x$} & \multirow{4}{*}{$\mathrm{GC}$} & 40,1 \\
\hline & & 39,6 \\
\hline \multirow{2}{*}{$14 \mathrm{x}$} & & 36,1 \\
\hline & & 39,8 \\
\hline \multirow{2}{*}{$15 x$} & \multirow{4}{*}{ GD } & 63,7 \\
\hline & & 60,4 \\
\hline \multirow{2}{*}{$16 x$} & & 68,6 \\
\hline & & 69,8 \\
\hline
\end{tabular}

Tablica 12. Wyniki pomiarów przewodności elektrycznej właściwej dla próbek pobranych z głębokości $0,3 \div 1,5 \mathrm{~m}$ ppt

\begin{tabular}{|c|c|c|}
\hline Numer próbki & $\begin{array}{c}\text { Badany obszar } \\
\text { w miejscowości B }\end{array}$ & $\begin{array}{c}\text { Przewodność } \\
{[\mu \mathrm{S} / \mathrm{cm}]}\end{array}$ \\
\hline \multirow{2}{*}{$1 \mathrm{x}$} & \multirow{4}{*}{ BA } & 51,2 \\
\hline & & 53,2 \\
\hline \multirow{2}{*}{$2 \mathrm{x}$} & & 47,5 \\
\hline & & 49,4 \\
\hline \multirow{2}{*}{$3 x$} & \multirow{4}{*}{$\mathrm{BB}$} & 39,5 \\
\hline & & 40,8 \\
\hline \multirow{2}{*}{$4 x$} & & 39,3 \\
\hline & & 40,2 \\
\hline \multirow{2}{*}{$5 \mathrm{x}$} & \multirow{4}{*}{$\mathrm{BC}$} & 46,0 \\
\hline & & 47,6 \\
\hline \multirow{2}{*}{$6 x$} & & 51,4 \\
\hline & & 45,2 \\
\hline \multirow{2}{*}{$7 \mathrm{x}$} & \multirow{4}{*}{$\mathrm{BD}$} & 41,7 \\
\hline & & 43,6 \\
\hline \multirow{2}{*}{$8 \mathrm{x}$} & & 42,3 \\
\hline & & 43,0 \\
\hline
\end{tabular}

\begin{tabular}{|c|c|c|}
\hline Numer próbki & $\begin{array}{c}\text { Badany obszar } \\
\text { w miejscowości G }\end{array}$ & $\begin{array}{c}\text { Przewodność } \\
{[\mu \mathrm{S} / \mathrm{cm}]}\end{array}$ \\
\hline \multirow{2}{*}{$9 \mathrm{x}$} & \multirow{4}{*}{ GA } & 41,3 \\
\hline & & 44,4 \\
\hline \multirow{2}{*}{$10 \mathrm{x}$} & & 35,3 \\
\hline & & 37,8 \\
\hline \multirow{2}{*}{$11 x$} & \multirow{4}{*}{ GB } & 27,4 \\
\hline & & 28,3 \\
\hline \multirow{2}{*}{$12 x$} & & 30,0 \\
\hline & & 30,8 \\
\hline \multirow{2}{*}{$13 x$} & \multirow{4}{*}{$\mathrm{GC}$} & 15,4 \\
\hline & & 15,5 \\
\hline \multirow{2}{*}{$14 \mathrm{x}$} & & 15,9 \\
\hline & & 15,9 \\
\hline \multirow{2}{*}{$15 \mathrm{x}$} & \multirow{4}{*}{ GD } & 48,8 \\
\hline & & 48,4 \\
\hline \multirow{2}{*}{$16 x$} & & 36,1 \\
\hline & & 38,6 \\
\hline
\end{tabular}

Jak wynika z powyższych obliczeń największy udział w oszacowanej niepewności pomiaru dla wszystkich omawianych w artykule metod ma składowa związana z etapem pobierania próbek. Nie przekracza ona jednak 20\%. Można więc stwierdzić, że (w sprawdzanym zakresie pomiaro-

wym) metoda pobierania próbek wykorzystywana w Zakładzie Ochrony Środowiska Instytutu Nafty i Gazu - PIB jest odpowiednia do prowadzenia oceny stanu środowiska glebowego i zgodna z obowiązującymi w tym zakresie wymaganiami prawa. 
Tablica 13. Dane otrzymane w trakcie szacowania niepewności dla analizowanych zbiorów wyników badań

\begin{tabular}{|c|c|c|c|c|}
\hline \multirow{3}{*}{ Oznaczany parametr } & \multirow{3}{*}{$\begin{array}{c}\text { Głębokość pobrania } \\
\text { próbek gleby } \\
{[\mathrm{m} \mathrm{ppt}]}\end{array}$} & \multicolumn{3}{|c|}{ Niepewność względna, przy przedziale ufności 95\%, $k=2$} \\
\hline & & $\begin{array}{c}U_{\text {sampl }}^{\prime} \\
\text { pobieranie próbki }\end{array}$ & $\begin{array}{c}U_{\text {anal }}^{\prime} \\
\text { proces analityczny }\end{array}$ & $\begin{array}{l}U_{\text {meas }}^{\prime} \\
\text { pomiar }\end{array}$ \\
\hline & & \multicolumn{3}{|c|}{$[\%]$} \\
\hline \multirow{2}{*}{ Zawartość wody } & $0,0 \div 0,3$ & 16,6 & 3,0 & 16,9 \\
\hline & $0,3 \div 1,5$ & 10,1 & 1,6 & 10,2 \\
\hline \multirow{2}{*}{$\mathrm{pH} w \mathrm{H}_{2} \mathrm{O}$} & $0,0 \div 0,3$ & 3,3 & 0,9 & 3,4 \\
\hline & $0,3 \div 1,5$ & 2,1 & 0,8 & 2,2 \\
\hline \multirow{2}{*}{$\mathrm{pH}$ w $\mathrm{KCl}$} & $0,0 \div 0,3$ & 3,8 & 0,6 & 3,8 \\
\hline & $0,3 \div 1,5$ & 3,2 & 0,8 & 3,3 \\
\hline \multirow{2}{*}{$\begin{array}{l}\text { Przewodność } \\
\text { elektryczna właściwa }\end{array}$} & $0,0 \div 0,3$ & 6,9 & 8,9 & 11,2 \\
\hline & $0,3 \div 1,5$ & 12,0 & 7,0 & 13,9 \\
\hline
\end{tabular}

\section{Podsumowanie}

Najbardziej uniwersalną metodą pozwalającą na określenie stopnia zanieczyszczenia gleby substancjami i związkami chemicznymi jest jej analiza fizykochemiczna. Do wykonania analizy konieczne jest właściwe pobranie próbek gleby, które stanowi jeden z kluczowych etapów gwarantujących poprawność otrzymanego wyniku. Prawodawstwo unijne nie określa sposobu pobierania próbek gleby w kontekście prowadzenia oceny zanieczyszczenia powierzchni ziemi.

Sposób pobrania, przygotowania oraz metodyki referencyjne, które należy wykorzystywać w celu oceny zanieczyszczenia powierzchni ziemi podane są natomiast w rozporządzeniu Ministra Środowiska z dnia 1 września 2016 r. w sprawie sposobu prowadzenia oceny zanieczyszczenia powierzchni ziemi [6, 19].

Ocena zanieczyszczenia powierzchni ziemi wymaga przeważnie wykonania pomiarów stanowiących część szerszych badań, których celem jest poznanie właściwości całego obiektu lub określenie, w jaki sposób zmieniają się badane cechy w czasie i/lub w przestrzeni. Uwzględnienie niepewności pochodzącej z etapu pobierania próbek zwiększa przedział niepewności pomiaru, ale jednocześnie go określa. Wyniki z przypisaną niepewnością uwzględniającą etap pobierania próbek są wiarygodne i reprezentatywne dla badanego obszaru, a nie tylko dla badanej próbki.

Przeprowadzono obliczenia niepewności pomiaru na podstawie wyników otrzymanych dla próbek podwójnych na podstawie planu zrównoważonego, który dostarcza informacji o poszczególnych składowych niepewności pomiaru. Dla wszystkich analizowanych w ramach pracy metod składowa niepewności pochodząca z pobierania próbek ma największy udział w niepewności pomiaru.

Prosimy cytować jako: Nafta-Gaz 2018, nr 3, s. 215-225, DOI: 10.18668/NG.2018.03.05

Arykuł nadesłano do Redakcji 29.11.2017 r. Zatwierdzono do druku 23.01.2018 r.

Artykuł powstał na podstawie pracy statutowej pt.: Weryfikacja sposobu pobierania próbek gleby w kontekście prowadzenia oceny zanieczyszczenia powierzchni ziemi - praca INiG - PIB na zlecenie MNiSW; nr zlecenia: 0066/GE/17, nr archiwalny: DK-4100-0053/17.

\section{Literatura}

[1] Dołęgowska S.: Estimation of plant sampling uncertainty: an example based on chemical analysis of moss samples. Environmental Science and Pollution Research 2016, vol. 23, nr 22, s. 22623-22632, DOI: 10.1007/s11356-016-7477-4.

[2] Dołęgowska S., Gałuszka A.: Heterogeneous areas - identification of outliers and calculation of soil sampling uncertainty using the modified RANOVA method. Environmental Monitoring and Assessment 2016, vol. 188, s. 581, DOI:10.1007/s10661016-5584-9.

[3] Dołęgowska S., Gałuszka A., Migaszewski Z.M.: An impact of moss sample cleaning on uncertainty of analytical measurement and pattern profiles of rare earth elements. Chemosphere 2017, vol. 188, s. 190-198, DOI: 10.1016/j. chemosphere.2017.08.161.

[4] Haduch B.: Wpływ procesu pobierania próbek na jakość przewidywania nieaddytywnych właściwości benzyn silnikowych. Nafta-Gaz 2014, nr 10, s. 717-723.

[5] Kluk D., Steliga T.: Ocena zmian toksyczności gleby skażonej niklem i substancjami ropopochodnymi w procesach fitoremediacji. Nafta-Gaz 2016, nr 4, s. 230-241, DOI: 10.18668/ NG.2016.04.02.11.

[6] Kostecki J., Fruzińska R.: Ochrona gleb w świetle prawa krajowego i europejskiego. Zeszyty Naukowe Uniwersytetu Zielonogórskiego, seria Inżynieria Środowiska 2012, t. 146, s. 5-14.

[7] Kostka A.: Porównanie wyników szacowania niepewności pomiaru na podstawie próbek dublowanych $w$ monitoringu jakości wód podziemnych wedtug różnych schematów badań. Przegląd Geologiczny 2015, vol. 63, nr 10/1, s. 834-839. 
[8] Kukulska-Zając E., Król A., Dobrzańska M.: Prowadzenie oceny stanu środowiska glebowego pod kątem występowania zanieczyszczeń węglowodorami w aspekcie obowiąujacych uregulowań prawnych. Nafta-Gaz 2017, nr 5, s. 350-359, DOI: 10.18668/NG.2017.05.06.

[9] Niepewność pomiaru zwiąana z pobieraniem próbek. Przewodnik metodyczny. Wykorzystanie informacji o niepewności pomiaru do oceny zgodności. Biuletyn Informacyjny Klubu POLLAB 1/52/2009, wydanie 1, 2007, ISSN 1428-6009.

[10] Strona internetowa: http://www.rsc.org/ (dostęp: październik 2017).

[11] de Zorzi P., Barbizzi S., Belli M., Barbina M., Fajgelj A., Jacimovic R., Jeran Z., Menegon S., Pati A, Petruzzelli G., Sansone U., van der Perk M.: Estimation of uncertainty arising from different soil sampling devices: The use of variogram parametres. Chemosphere 2008, vol. 70, nr 5, s. 745-752, DOI: 10.1016/j.chemosphere.2007.07.068.

\section{Akty prawne i normatywne}

[12] Dyrektywa Parlamentu Europejskiego i Rady 2010/75/UE z dnia 24 listopada 2010 r. w sprawie emisji przemysłowych (zintegrowane zapobieganie zanieczyszczeniom i ich kontrola) (Dz.U. UE L 334 z 17 grudnia 2010 r., wraz z późn. zm.).

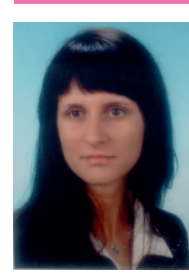

Mgr Monika Gajec

Starszy specjalista inżynieryjno-techniczny

w Zakładzie Ochrony Środowiska

Instytut Nafty i Gazu - Państwowy Instytut Badawczy ul. Lubicz 25 A

31-503 Kraków

E-mail: monika.gajec@inig.pl

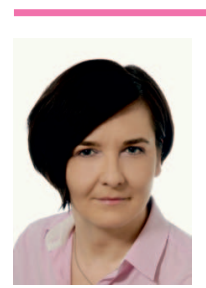

Dr Ewa KUKULSKA-ZAJĄC

Adiunkt; kierownik Zakładu Ochrony Środowiska.

Instytut Nafty i Gazu - Państwowy Instytut Badawczy ul. Lubicz 25 A

31-503 Kraków

E-mail: kukulska@inig.pl
[13] Dyrektywy IED, tj. Dyrektywy Parlamentu Europejskiego i Rady 2010/75/UE z dnia 24 listopada 2010 r. w sprawie emisji przemysłowych (zintegrowane zapobieganie zanieczyszczeniom i ich kontrola) (Dz.U. UE L 334 z 17 grudnia 2010 r.).

[14] Norma PN-ISO 10381-1:2008 Jakość gleby-Pobieranie próbek-Część 1: Zasady opracowywania programów pobierania próbek.

[15] Norma PN-ISO 10381-2:2007 Jakość gleby - Pobieranie próbek-Czesść 2: Zasady dotyczace technik pobierania.

[16] Norma PN-ISO 10381-3:2007 Jakość gleby-Pobieranie próbek-Część 3: Zasady dotyczace bezpieczeństwa.

[17] Norma PN-ISO 10381-4:2007 Jakość gleby - Pobieranie próbek - Część 4: Zasady dotyczace postępowania podczas badań terenów naturalnych, zbliżonych do naturalnych oraz uprawnych.

[18] Norma PN-ISO 10381-5:2009 Jakość gleby - Pobieranie próbek-Część 5: Zasady podczas prowadzenia badań terenów miejskich oraz przemysłowych pod katem zanieczyszczenia gleby.

[19] Rozporządzenie Ministra Środowiska z dnia 1 września 2016 r. w sprawie sposobu prowadzenia oceny zanieczyszczenia powierzchni ziemi (Dz.U. z 2016 r., poz. 1395).

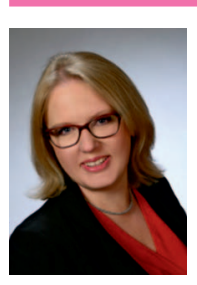

Mgr Anna KRÓL

Starszy specjalista badawczo-techniczny w Zakładzie Ochrony Środowiska.

Instytut Nafty i Gazu - Państwowy Instytut Badawczy ul. Lubicz 25 A

31-503 Kraków

E-mail: anna.krol@inig.pl

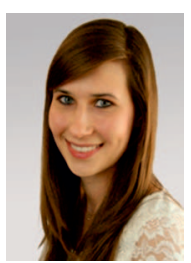

Mgr Justyna MOSTOWSKA-STĄSIEK

Specjalista inżynieryjno-techniczny w Zakładzie

Ochrony Środowiska

Instytut Nafty i Gazu - Państwowy Instytut Badawczy ul. Lubicz $25 \mathrm{~A}$

31-503 Kraków

E-mail: mostowska@inig.pl 